\title{
PEMBELAJARAN SETS (SCIENCE, ENVIRONMENT, TECHNOLOGY, SOCIETY): PENGARUHNYA PADA KETERAMPILAN PROSES SAINS
}

\section{SETS LEARNING (SCIENCE, ENVIRONMENT, TECHNOLOGY, SOCIETY): THE EFFECT ON SCIENCE PROCESS SKILLS}

\author{
Melta Zahra ${ }^{1}$, Widya Wati ${ }^{2}$, Deden Makbuloh ${ }^{3}$ \\ ${ }^{1}$ Prodi Pendidikan Fisika Program Pascasarjana Universitas Negeri Yogyakarta \\ ${ }^{2}$ Prodi Pendidikan Fisika Fakultas Tarbiyah dan Keguruan Universitas Islam Negeri Raden Intan Lampung \\ ${ }^{3}$ Prodi Pendidikan Agama Islam Fakultas Tarbiyah dan Keguruan Universitas Islam Negeri Raden Intan \\ Lampung \\ E-mail: meltazahra52@gmail.com
}

Diterima: 15 September 2019. Disetujui: 17 Oktober 2019. Dipublikasikan: 29 November 2019

\begin{abstract}
This study aims to determine the effect of learning SETS (Science, Environment, Technology, Society) to the science process skills student. To see student process skilss researcher using test and observations. This Study included a type of quasi Ekperimental research. This study uses experimental class and control class. Sampling technique used cluster samplin. To know the difference of mastery science process skills experimental class and control class do t-test by the formula Polled varians. Analysis results showing $t_{\text {hitung }}=11,1223$ while $t_{\text {tabel }}=1,9908$ with a significant level $0,05 \%$ so $t_{\text {hitung }}>t_{\text {tabel. }} H_{1}$ be accepted, there is influence of learning SETS (Science, Environment, Technology, Society) to the science process skills. It can be concluded that there is influence of learning SETS (Science, Environment, Technology, Society) to the science process skills.
\end{abstract}

Keywords: science process skill, SETS learning

\begin{abstract}
Abstrak: Penelitian ini bertujuan untuk mengetahui Pengaruh pembelajaran SETS (Science, Environment, Technology, Society) terhadap keterampilan proses sains peserta didik. Untuk melihat penguasan keterampilan proses peserta didik peneliti mengunakan tes dan observasi. Penelitian ini termasuk jenis penelitian quasi eksperimen. Penelitian ini menggunakan kelas eksperimen dan kelas kontrol. Teknik pengambilan sampel yang digunakan cluster sampling. Untuk mengetahui perbedaan penguasaan keterampilan proses sains expekelas kontrol dan kelas eksperimen dilakukan uji-t dengan rumus Polled Varians. Hasil analisis menunjukan $t_{\text {hitung }}=11,1223$ sedangkan $t_{\text {tabel }}=1,9908$ dengan taraf signifikan $0,05 \%$ sehingga $t_{\text {hitung }}>\mathrm{t}_{\text {tabel. }} \mathrm{H}_{1}$ diterima, terdapat pengaruh model Pembelajaran SETS (Science, Environment, Technology and Society) terhadap keterampilan proses sains. sehungga Dapat simpulkan bahwa terdapat pengaruh model pembelajaran SETS dalam meningkatkan keterampilan proses sains peserta didik.
\end{abstract}

(C) 2019 Unit Riset dan Publikasi Ilmiah FTK UIN Raden Intan Lampung

Kata Kunci: keterampilan proses sains, pembelajaran SETS

\section{PENDAHULUAN}

Mutu Pendidikan indonesia perlu ditingkatkan salah satunya dengan memperbaiki kurikulum, sarana pendidikan, serta pengelolaan dan pendayagunan laboratorium. Selain itu dalam proses belajar mengajar yang mencakup cara mengajar, metode serta pendekatan yang digunakan.(Wahdah, Muris, \& Arsyad, 2017).

Fisika adalah bidang ilmu yang mempelajari alam dan gejalanya, dari yang bersifat nyata sampai yang bersifat abstrak. Belajar fisika dapat membantu peserta didik memahami alam sekitar dengan penyelidikan. (Amalia, Indrawati, 
\& Subiki, 2017) Pembelajaran fisika yang baik dalam menemukan pengetahuan dengan mengikuti langkahlangkah ilmiah.(Atminiati \& Binadja, 2017).

Berdasarkan hasil observasi yang telah dilakukan pada pendidik mata pelajaran fisika kelas X MIA MAN 2 Bandar Lampung. Diketahui pada saat proses pembelajaran yang diterapkan mengunakan pembelajaran didominasi oleh pendidik. Pembelajaran cenderung mengunakan metode ceramah, materi yang diberikan kurang mengaitkan isi pelajaran dengan kehidupan sehari-hari, Dimana pelajaran lebih banyak di isi dengan latihan soal. Penilaian keterampilan proses sains belum di terapkan secara khusus.

Data keterampilan proses sains diperoleh melalui observasi dan portofolio. Melatih keterampilan proses dalam pembelajaran fisika dapat membantu peserta didik untuk, meningkatkan pemahaman tentang materi yang dipelajari.

Ada banyak Model pembelajaran yang dapat diterapkan dalam pembelajaran fisika salah satu pembelajaran bervisi SETS. Pembelajaran bervisi SETS, peserta didik diajak untuk mengkaitkan antara unsur sains dalam pembelajaran yang sedang diikuti dengan unsur lingkungan, teknologi dan masyarakat.(Atminiati \& Binadja, 2017) Pembelajaran SETS juga membatu Peserta didik dalam memanfaatkan lingkungan sekolah memperoleh informasi berdasarkan materi yang dipelajari, peserta didik memanfaatkan lingkungan sekitar sekolah untuk mengamati benda-benda yang ada di sekitar sekolah. Kemudian peserta didik memanfaatkan masyarakat untuk berinteraksi dalam menemukan informasi, jadi peserta didik tidak hanya diajarkan untuk memanfaatkan lingkungan untuk memperoleh informasi tetapi juga memanfaatkan masyarakat untuk memperoleh informasi. Serta peserta didik dapat menerapkan teori yang dipelajari dengan teknologi yang ada. Tujuan dari Penelitian ini untuk melihat pengaruh Pembelajran SETS (Science, Environment, Technology, Society) terhadap keterampilan proses sains peserta didik.

\section{LANDASAN TEORI}

Model pembelajaran sains teknologi dan masyarakat merupakan pembelajaran yang mengaitkan sains dan teknologi serta manfaatnya bagi masyarakatnya. Tujuan untuk membentuk peserta didik memiliki literasi sains dan teknologi serta peduli terhadap masalah masyarakat dan lingkungan disekitarnya.(Poedjiadi, 2010) Dalam konteks pendidikan bervisi SETS, urutan ringkasan SETS membawa pesan bahwa untuk menggunakan sains (S) ke bentuk teknologi $(\mathrm{T})$ dalam memenuhi kebutuhan masyarakat (S-kedua) diperlukan pemikiran tentang berbagai implikasinya pada lingkungan (E) secara fisik maupun mental. (Fatchan \& Soekamto, 2014) Pembelajaran SETS terdiri dari lima tahapan yaitu inisiasi, pengembangan konsep, aplikasi konsep dan pemantapan konsep serta penilaian.

Keunggulan dari model pembelajaran SETS dapat Melatih peserta didik melakukan metode kerja ilmiah. Sehingga peserta didik mampu membuat karya ilmiah yang tertata dan terorganisasi dengan baik. Meningkatkan kemampuan peserta didik dalam berkomunikasi. Membuat pembelajaran menjadi menyenangkan. Membantu peserta didik mengenal dan memahami sains dan teknologi serta dampak negatif yang bisa ditimbulkan dalam kehidupan seharihari.(Wahdah et al., 2017)

Keterampilan proses sains merupakan proses mencari dan menemukan, dimana proses pembelajaran dilakukan dengan memberikan pengalaman langsung pada peserta didik dengan langkah-langkah 
kerja ilmiah sesuai dengan yang dilakukan para ilmuwan. (Jufri, 2013)

Pembelajaran IPA diperlukan penyelidikan, secara observasi maupun eksperimen, sebagai kerja ilmiah yang melibatkan keterampilan proses sikap ilmiah. Melalui kerja ilmiah, peserta didik dapat memanfaatkan fakta, membangun konsep, prinsip, teori sebagai dasar untuk berpikir kreatif, kritis, analitis, dan divergen. Metode praktikum yang digunakan dalam pembelajaran dengan mengaplikasikan keterampilan proses sains dapat membuat siswa terlatih dan menjadi terampil dalam mengemukakan dan mengembangkan teori dan konsep yang dipelajari.(Ria, 2014).

Indikator keterampilan proses sains terdiri dari keterampilan proses dasar yaitu(Jufri, 2013): mengamati, mengukur, memprediksi, mengelompokkan, menginferensi, dan mengkomunikasikan.

\section{METODE PENELITIAN}

Penelitian ini mengambil penelitian Quasi Experimental dengan desain randomized control group only pascatest design. pada penelitian ini terdapat dua variabel yaitu variabel terikatnya adalah keterampilan proses sains dan Variabel Bebas Model pemebelajaran SETS (Science, Environment, Technology, Society).

Penelitian dilakasanakan di Madrasah Aliyah Negeri 2 Bandar Lampung semester genap tahun ajaran 2017/2018. Populasi pada penelitian ini adalah seluruh peserta didik pada kelas X MIA yang berjumlah 138 yang terdiri dari 4 kelas. Sampel pada penelitian ini terdiri dari 2 kelas yang berjumlah 72 peserta didik, yaitu kelas $\mathrm{X}$ MIA 1 yang berjumlah 38 peserta didik sebagai kelas eksperimen. Dan kelas XI MIA 2 yang berjumlah 38 peserta didik sebagai kelas kontrol.

Teknik pengambilan sampel yang digunakan pada penelitian ini adalah cluster sampling (Sugiyono, 2016).
Instrumen penelitian di artikan sebagai alat ukur dalam penelitian untuk menjawab pertanyaan-pertanyaan dan menguji hipotesis penelitian. Jenis instrumen dalam penelitian ini berupa tes essay, dimana tiap soal mengukur indikator keterampilan proses sains yang berbeda. Sebelum Soal digunakan untuk penelitian terlebih dahulu diuji validitas, reliabilitas, daya beda dan tingkat kesukaran. Analisis data untuk menguji normalitas, homogenitas dan hipotesis.

Untuk menguji hipotesis mengunakan uji t. Uji hipotesis ini dilakukan dengan menggunakan rumus polled varians sebagai berikut: (Sugiyono, 2014)

Keterangan:

$$
t_{\text {hitung }}=\frac{X 1-X 2}{\sqrt{\frac{(n 1-1) S 1^{2}+(n 2-1) S 2^{2}}{n 1+n 2-2}}\left(\frac{1}{n 1}+\frac{1}{n 2}\right)}
$$

$X_{1}$ : Nilai rata-rata post test dari kelas eksperimen

$X_{2}$ : Nilai rata-rata post test dari kelas kontrol

$n_{1}$ : Jumlah sampel kelas eksperimen

$n_{2}$ : Jumlah sampel kelas control

$S_{1}$ : varians dari kelas eksperimen

$S_{2}$ : varians dari kelas kontrol

Kriteria Uji :

Setelah dilakukan penghitungan sesuai dengan rumus, maka pengujian dengan melihat perbandingan antara $t_{\text {hitung }}$ dan $t_{\text {tabel }}$ di mana $t_{\text {tabel }}=t_{(n 1+n 2-1)}$ dengan taraf signifikan $\alpha=0,05$.

Kesimpulan :

Jika $t_{\text {hitung }} \leq \mathrm{t}_{\text {tabel }}$ maka $\mathrm{H}_{0}$ diterima. Teknik Analisis Data Keterampilan Proses Sains

Instrumen keterampilan proses sains yang kedua berupa lembar observasi keterampilan proses sains. Dalam teknik analisis lembar observasi yang akan dinilai adalah aspek dari keterampilan proses sains dengan skala likert. Adapun tahapan analisisnya adalah:

1. Menjumlahkan indikator dari aspek KPS yang diamati.

2. Analisis data hasil penilaian lembar observasi keterampilan proses sains 
mengunakan skala likert dengan persamaan sebagai berikut :

$$
\% \text { KPS }=\frac{\text { skor yang diperoleh }}{\text { skor maksimal }} \times 100
$$

Tabel 1. Kriteria Interpretasi Skor

\begin{tabular}{cc}
\hline Presentase & Keterangan \\
\hline $81-100$ & Sangat Baik \\
$61-80$ & Baik \\
$41-60$ & Cukup \\
$21-40$ & Kurang \\
$0-20$ & Sangat Kurang \\
\hline
\end{tabular}

\section{HASIL DAN PEMBAHASAN}

Data-data hasil penelitian berupa hasil lembar observasi keterampilan proses sains dan tes berupa uraian sebanyak 10 soal.

Tabel 2. Hasil Pretest dan posttest kelas kontrol dan kelas eksperimen

\begin{tabular}{lccc}
\hline Kelas & Pretest & Posttest & N-gain \\
\hline Kontrol & 39,94 & 62,56 & 0,37 \\
Eksperimen & 40,96 & 81,54 & 0,68 \\
\hline
\end{tabular}

Berdasarkan tabel diatas menunju kan bahwa nilai rata-rata Postest kelas kontrol lebih rendah diandingkan kelas eksperimen. Hal ini menunjukan hasil NGain Kelas Kontrol lebih kecil dibanding N-Gain Kelas eksperimen. Maka dapat disimpulkan bahwa pem belajaran dengan mengunakan model pembelajaran SETS (Sains, Environment, Technology, and Society) yang diberikan dikelas eksperimen mampu meningkatkan keterampilan proses sains peserta didik.

Observasi dilaksanakan pada saat pembelajaran berlangsung dengan diadakannya praktikum. Hal yang diamati berupa indikator indikator pada keterampilan proses sains peserta didik saat pembelajaran berlangsung, Berikut ini hasil lembar observasi keterampilan proses sains.

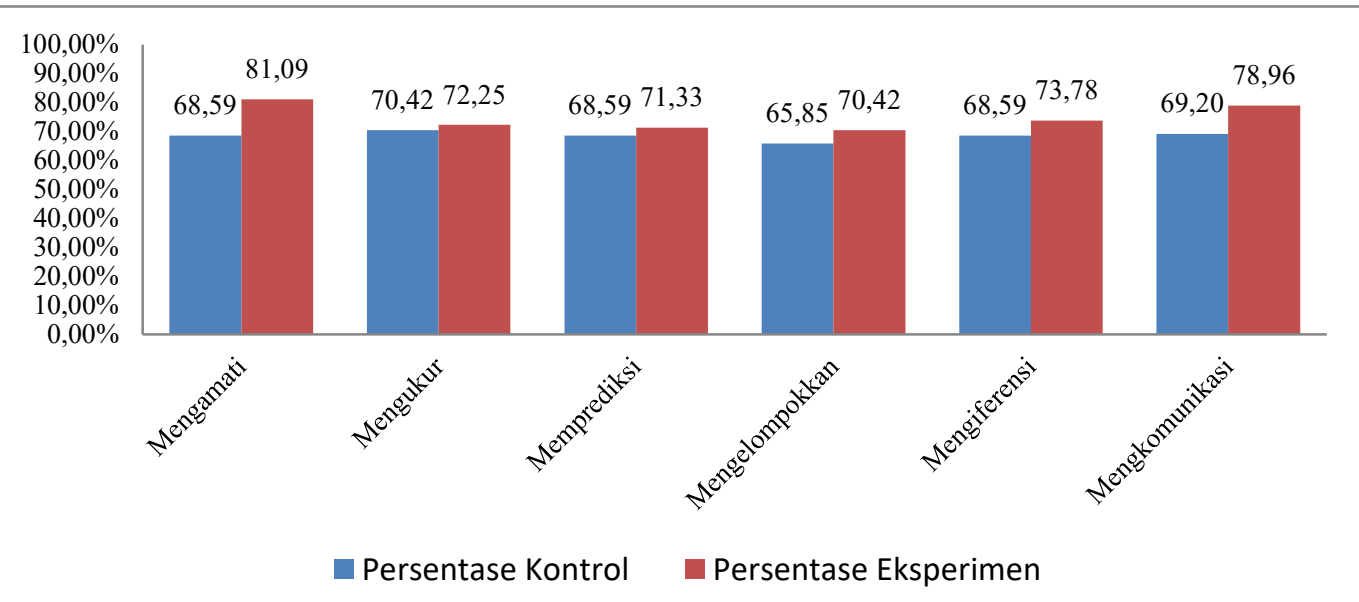

Gambar 1. Diagram hasil observasi keterampilan proses sains

\section{Uji Normalitas}

Uji normalitas digunakan untuk mengetahui data terdistribusi normal atau tidak. Untuk menguji normalitas pada penelitian ini mengunakan uji liliefors (dengan taraf signifikan $\alpha=0,005$ ) dengan mengunakan aplikasi microsoft excel. Data terdistribusi normal jika nilai signifikan $>0,05$. Jika nilai signifikan $<$ 0,05 maka data tidak terdistribusi normal. Hasil uji normalitas yang digunakan uji liliefors, menunjukan data terdistribusi normal. 
Tabel 3. Hasil uji Normalitas pada kelas kontrol dan kelas eksperimen

\begin{tabular}{llccc}
\hline \multicolumn{1}{c}{ Data } & & $\mathbf{L}_{\text {Tabel }}$ & $\mathbf{L}_{\text {hitung }}$ & Kesimpulan \\
\hline Kelas Eksperimen & Pretest & 0,142 & 0,108 & $\mathrm{~L}_{\text {hitung }}<\mathrm{L}_{\text {tabel }}$ \\
& & $\mathrm{N}=39$ & & Data terdistribusi \\
& Posttest & & 0,135 & normal \\
& Per. I & & 0,134 & \\
Kelas Kontrol & Per.II & & 0,133 & \\
& Pretest & 0,138 & 0,112 & \\
& & $\mathrm{~N}=41$ & & \\
& Posttest & & 0,127 & 128 \\
& Per. I & & 124 & \\
\hline
\end{tabular}

Berdasarkan tabel hasil uji normalitas kelas eksperimen dan kontrol dengan pretest, posttest dan Lembar Observasi dengan taraf signifikan 0,05 . Hasil uji normalitas Pada kelas eksperimen di peroleh nilai $\mathrm{L}_{\text {hitung }}<\mathrm{L}_{\text {tabel}}$, sehingga $\mathrm{H}_{0}$ diterima pada data kelas eksperimen terdistribusi normal dan hasil uji normalitas kelas kontrol diperoleh nilai $\mathrm{L}_{\text {hitung }}<\mathrm{L}_{\text {tabel }}$ sehingga data pada kelas kontrol terdistribusi normal. Sehingga data keterampilan proses sains terdistribusi Normal.

\section{Uji Homogenitas}

Uji homogenitas pada penelitian ini mengunakan Uji homogenitas dua varians dengan taraf signifikan $\alpha=0,005$ digunakan untuk menguji apakah kedua data tersebut homogen. Dan apakah sampel yang digunakan memiliki varian yang sama atau tidak. Adapun kriteria penerimaan data homogen adalah jika $\mathrm{F}_{\text {hitung }}<\mathrm{F}_{\text {tabel }}, \mathrm{H}_{0}$ diterima maka sampel homogen dan jika $F_{\text {hitung }}>F_{\text {tabel }}$ maka sampel tidak homogen. Berikut hasil uji homogenitas disajikan pada tabel 4 .

Tabel 4. Hasil Uji Homogenitas Kelas Eksperimen dan Kontrol

\begin{tabular}{cccc}
\hline Data & $\mathbf{F}_{\text {Tabel }}$ & $\mathbf{F}_{\text {hitung }}$ & Kesimpulan \\
\hline Pretest & 1,7012 & 0,9984 & $\mathrm{~F}_{\text {hitung }}<\mathrm{F}_{\text {tabel }}$ data dinyatakan \\
Posttest & & 0,7191 & homogen $\mathrm{H}_{1}$ diterima. \\
Per. I & & 0,8318 & \\
Per.II & & 0,9873 & \\
\hline
\end{tabular}

Hasil uji homogenitas pada kelas kontrol dan kelas eksperimen memiliki $\mathrm{F}_{\text {hitung }}<\mathrm{F}_{\text {tabel }}$ sehingga dapat disimpulkan bahwa $\mathrm{H}_{1}$ diterima artinya populasi tersebut memiliki varians yang sama. Setelah diketahui data memiliki varians yang sama maka dapat dilanjutkan dengan mengunakan statistik parametik yaitu uji t.

\section{Hasil pengujian hipotesis}

Berdasarkan data yang telah di uji normalitas dan homogenitas kemudian data dinyatakan normal dan homogen, maka dilanjutkan dengan pengujian hipotesis dengan mengunakan statistika parametris yaitu uji-t. Pengujian hipotesis dilakukan untuk mengetahui adakah pengaruh perlakuan dengan mengunakan model pembelajaran SETS (Sains, Environment, Technology, and Society) terhadap ketrampilan proses sains peserta didik kelas eksperimen dan kelas kontrol.

Adapun kriteria penerimaan data terdapat perbedaan atau tidak adalah sebagai berikut :

Jika $t_{\text {hitung }} \leq \mathrm{t}_{\text {tabel }}$ maka $\mathrm{H}_{0}$ diterima, $\mathrm{H}_{1}$ ditolak.

Jika $t_{\text {hitung }}>t_{\text {tabel }}$ maka $\mathrm{H}_{1}$ diterima, $\mathrm{H}_{0}$ ditolak.

Berikut hasil uji hipotesis yang disajikan pada tabel5. 
Tabel 5. Hasil uji hipotesis Keterampilan proses sains

\begin{tabular}{lccc}
\hline \multicolumn{1}{c}{ Data } & $\mathbf{T}_{\text {hitung }}$ & $\mathbf{t}_{\text {Tabel }}$ & Kesimpulan \\
\hline Tes & 11,1223 & 1,9908 & $\mathrm{~T}_{\text {hitung }}>\mathrm{T}_{\text {tabel }}$ maka $\mathrm{H}_{1 \text { Diterima. }}$ \\
Observasi & 11,0396 & 1,9908 & \\
\hline
\end{tabular}

Berdasarkan uji $\mathrm{t}$ dari kelas kontrol dan kelas eksperimen berupa tes dan observasi maka didapat hasil hipotesis dengan taraf signifikan 0,05 diperoleh $t_{\text {hitung }}$ lebin besar daripada $t_{\text {tabel }}$ sehingga $\mathrm{t}_{\text {hitung }}>\mathrm{t}_{\text {tabel. }}$. Maka $\mathrm{H}_{1}$ diterima. Dengan demikian dapat disimpulkan bahwa terdapat pengaruh model Pembelajaran SETS (Science, Environment, Technology and Society) terhadap keterampilan proses sains.

Pembelajaran SETS mengaitkan empat unsur yaitu sains, Lingkungan, Teknologi dan Masyarakat. Sehingga dengan keempat unsur tersebut dapat meningkatkan keterampilan proses sains peserta didik. Pada masing masing unsur SETS terdapat hubungan terhdap Keterampilan proses sains peserta didik. Seperti Science pada indikator mengukur, Environment dengan Mengamati dan Mengelompokkan, Technology pada indikator memprediksi dan pada unsur Society indikator mengkomunikasi.

Berdasarkan hasil Penelitian Nofia nur miftiana, andari puji astuti, fitria faticatul hidaya bahwa model pembelajaran SETS dapat mengarahkan pola sikap peserta didik dalam bersosialisasi dan meningkatkan daya pikir terutama pada ilmu kimia yang diterapkan dalam kehidupan seharihari.(Miftianah, Astuti;, \& Hidayah, 2015)

Observasi yang dilakukan pada penelitian ini diaukan untuk mengetahui keterampilan proses sains peserta didik mengunakan model pembelajaran SETS pada materi usaha dan energi. Data yang di dapat pada hasil observasi keterampilan proses sains memperlihatkan indikator mengamati terletak pada hasil yang tertinggi sebesar $81,09 \%$ pada kelas eksperimen, Namun pada kelas kontrol indikator mengukur dengan hasil 70,42 $\%$.

Hasil keterampilan proses sains peserta didik yang memiliki kriteria sangat baik yaitu pada indikator mengamati dan menginterpretasi data dengan masing masing persentase yaitu $81,09 \%$ dan $78,96 \%$. Kemudian indikator keterampilan proses sains memiliki kriteria baik yaitu Mengamati dan Mengkomunikasi.

Setelah diterapkan model pembelajaran SETS dapat meningatkan keterampilan proses sains peserta didik terlihat pada masing masing indikator mendapat nilai yang tinggi. Namun pada indikator mengiteferensi terendah karena mayoritas peserta didik belum mampu mengemukan pendapat dengan menyatakan sesuatu berdasarkan hasil dari pengamatan sehingga peserta didik mendapatkan angka yang rendah pada indikator ini.

Penerapkan pembelajaran SETS didapatkan hasil observasi penguasaan keterampilan proses sains peserta didik lebih baik dibandingkan dengan pembelajaran konvensional. Ditinjau dari hasil persentase observasi pada setiap pertemuan meningkat. Pembelajaran SETS dapat melatih peserta didik untuk menguasai keterampilan proses, karena langkah langkah pada pembelajaran SETS cocok meningkatkan keterampilan proses sains peseta didik.

Pengujian hipotesis menggunakn uji-t terhadap hasil tes dan observasi keterampilan proses sains kelas eksperimen dan kelas kontrol. Pengujian ini dilakukan secara manual dengan mengunakn microsoft excel. pengaruh model Pembelajaran SETS (Science, Environment, Technology and Society) terhadap keterampilan proses sains. Kelas 
eksperimen lebih unggul dibanding dengan kelas kontrol. Hal ini disebabkan pada kelas eksperimen digunakan model pembelajarn SETS dimana peserta didik dapat menentukan sendiri permasalahan yang akan dipelajari dan memecahakan maslah tersebut dengan melibatkan sosial, teknologi dan lingkungan. Hal ini akan meningkatkan keterampilan proses sains peserta didik

Hasil penelitian kiky astyana terdapat perbedaan yang signifikan antara kelas yang menggunakan pembelajran SETS dan pada kelas yang tidak menggunakan SETS dapat dilihat dengan hasil uji t yaitu $t_{\text {hitung }}=7,225$ dengan taraf signifikan 5\% $t_{\text {tabel }}$ 2. (Kiky,2017)

Metode pembelajaran yang digunalkan pada kelas kontrol yaitu ceramah dan diskusi. Dalam interaksi pembelajaran sangat berpusat kepada guru sehingga belum bisa mengoptimalkan pembelajaran dan belum bisa mengaktifkan peserta didik. Peserta didik masih bergantung pada penjelasan guru sehingga kemampuan dan wawasan peserta didik masih minim. Selain itu sumber data atau kajian pustaka yang digunanakan pada kelas kontrol hanya bersumber dari buku cetak dan internet, sehingga materi yang mereka dapatkan terbatas. Hal ini berimbas pada kesulitan peserta didik dalam penguasaan memecahan masalah karena kurang memahami situasi dan kondisi yang ada dilapangan.

Persentase lembar observasi pada pertemuan pertama dan kedua terdapat peningkatan penguasaan keterampilan proses sains pada kelas yang diterapkan pemeblajaran SETS. Hal ini diperkuat dengan hasil persentase dari dua pertemuan. Karena keempat unsur SETS dapat memengaruhi penguasaan keterampilan proses peserta didik.

Hasil penelitian dalam pemebelajaran SETS peserta didik diajak untuk belajar dari pemasalahan permsalahan dalam dunia nyata, sehingga dapat meningkatkan keterampilan proses peserta didik. Dengan demikian hipotesis diterima, sehingga dapat disimpulkan terdapat pengaruh model pembelajaran SETS dalam meningkatkan keterampilan proses sains peserta didik.

\section{KESIMPULAN}

Berdasarkan landasan teori, analisis data, perhitungan $u j i-t$ dan mengacu pada rumusan masalah diketahui bahwa peserta didik yang menggunakan model pembelajaran (Science, Environment, Technology and Society) Hasil analisis menunjukan $t_{\text {hitung }}=11,1223$ sedangkan $t_{\text {tabel }}=1,9908$ dengan taraf signifikan $0,05 \%$ sehingga $t_{\text {hitung }}>t_{\text {tabel. }} H_{1}$ diterima, terdapat pengaruh model Pembelajaran SETS (Science, Environment, Technology and Society) terhadap keterampilan proses sains. Dapat simpulkan bahwa terdapat pengaruh model pembelajaran SETS dalam meningkatkan keterampilan proses sains peserta didik.

\section{DAFTAR PUSTAKA}

Amalia, M. R., Indrawati, \& Subiki. (2017). Model GI-GI (Group Investigation-Guided Inquiry) Dalam Pembelajaran Gerak Lurus Di SMA Negeri Rambipuji (Studi pada Aktivitas Belajar Siswa, Efektivitas Pembelajaran, dan Hasil Belajar Siswa). Jurnal Pembelajaran Fisika, 6(1).

Atminiati, E., \& Binadja, A. (2017). Keefektifan Pembelajaran Guided Note Taking Bervisi Sets Bermedia Chemo Edutainment Dalam Meningkatkan, 11(2).

Fatchan, A., \& Soekamto, H. (2014). Pengaruh Model Pembelajaran Science, Environment, Technology , Society ( SETS ) Terhadap Kemampuan Berkomunikasi Secara Tertulis Berupa Penulisan Karya Ilmiah bidang geografi siswa SMA. Jurnal Pendidikan Dan Pembelajaran, 21. 
Jufri, W. (2013). Belajar dan Pembelajaran Sains. Bandung: Pustaka Reka Cipta.

Miftianah, N. N., Astuti; A. P., \& Hidayah, F. F. (2015). Analisis Keterampilan Proses Kritis Siswa Melalui Pembelajaran SETS Kelas X Pada Materi Larutan Elektrolit dan NonElektrolit. Seminar Nasional Pendidikan, Sains Dan Teknologi Fakultas Matematika Dan Ilmu Pengetahuan Alam Universitas Muhammadiyah Semarang.

Poedjiadi, A. (2010). Sains Teknologi Masyarakat. Bandung: Remaja Rosdakarya.

Sugiyono. (2014). Metode Penliian Kuantitatif Kualikatif dan $R \& D$. Bandung: Alfabeta.

Sugiyono. (2016). Metode Penelitian Kuantitatif, Kualitatif dan $R \& D$. Bandung: Al.

Wahdah, Muris, \& Arsyad, N. (2017). Implementasi Stategi Pembelajaran Aktif Dalam Meningkatkan Kemampuan Menyelesaikan Masalah Fisika Pada Siswa Kelas VIII SMP Negeri 1 Sinjai Kabupaten Sinjai. Jurnal Pendidikan Fisika Universitas Muhammadiyah Makassar, 5.

Wisudawati, A. W., \& Sulistyowati, E. (2017). Metodologi Pembelajaran IPA. Jakarta: Bumi Aksara. 